Japan. J. Breed., 31(3): 251 260 (1981)

\title{
Anther Ontogeny in an Exotic and Six Indigenous Cytoplasmic Male Sterile Lines of Wheat (Triticum aestivum) Possessing Triticum timopheevi Cytoplasm
}

\author{
A. K. Jain*, R. K. S. Rathore*, S. V.S. Chauhan* \\ and Toshiro Kinoshita** \\ * Department of Botany, R. B.S. College, Agra (India) \\ ** Plant Breeding Institute, Faculty of Agriculture, \\ Hokkaido University, Sapporo, 060 Japan
}

\begin{abstract}
Anther ontogeny in an exotic cytoplasmic male-sterile (CMS) line 'Nadadores' and that in six indigenous CMS lines obtained through crosses with the former have been compared. In the exotic CMS line, pollen abortion was associated with nondegenerating and persistant tapetum. Similar abnormalities were recorded in the indigenous CMS lines also. Besides a few other tapetal abnormalities like degeneration of tapetum in premeiotic stages, tapetal hypertrophy in both pre and post-meiotic stages and pseudo-periplasmodium formation were also recorded. It is concluded on the basis of these observations that malfunctioning tapeta of various types are caused by inhibition of vascular tissue of the anther connective.
\end{abstract}

\section{Introduction}

The utilization of male sterility has progressed in the commercial production of hybrid seeds in self- and cross-pollinated crops (Duvick 1968, Heyne and Livers 1968). A number of cytoplasmic male sterile lines have been developed in wheat by Kinara (1951), Furasawa (1953, 1959) and WILson and Ross (1962) by the substitution of cytoplasmic background of Aegilops caudata, Ae. ovata and Triticum timopheevi in bread wheat genome respectively. The present paper is a part of the investigation carried out for transferring male-sterile character from an exotic CMS strain with $T$. timopheevi cytoplasm to some indigenous wheat varieties. The anther ontogeny in exotic as well as indigenous malesterile lines has been worked out and compared.

\section{Materials and Methods}

\section{Source of male-sterile cytoplasm and its transfer:}

The cytoplasmic male-sterile (CMS) strain of hexaploid wheat 'Nadadores' possessing Triticum timopheevi cytoplasm obrained from Dr. Don L. KEIM, spring wheat breeder, Cargill Research Farm, Colorado, U.S. A. was used in the present investigation. From this exotic male-sterile line pollinated by indigenous varieties, $\mathrm{HD}_{1593,}, \mathrm{HD}_{2009}, \mathrm{~K}_{7435}$, $\mathrm{UP}_{368}, \mathrm{WH}_{157}$ and $\mathrm{WL}_{711}, \mathrm{~F}_{1}$ hybrids were obtained and by repeated backcrossings, stable male sterile lines were selected.

Spikes of male-sterile lines with their fertile counterparts at different stages of development were fixed in formalin-alcohol. For morphological studies these spikelets were dehydrated through tertial-butyle alcohol series and embedded in paraffin wax. Serial microtome sections, 10-15 microns in thickness were stained with HeIDENHAIN's iron-alum haematoxylin and mounted in Euparol. Squashes of the anthers were made in $0.5 \%$

Received January 9, 1981 
acetocarmine.

\section{Observations}

\section{A. Anther ontogeny in fertile line:}

Early in anther ontogeny, each microsporangium differentiates into four distinct tissues, epidermis, two parietal layers, a seriate tapetum and the sporogenous mass. The tapetum is similar in appearance and behaviour throughout microsporogenesis on both external and internal connective sides of the locules. Microsporogenesis has been divided into seven stages. The sporangial tissues are initially evident, the last stage ends near the anthesis after the tapetal protoplasts have disintegrated, and the pollen grains have become engorged with reserve food material. The changes that occur during anther ontogeny in male-fertile and male-sterile lines are presented separately, but within the framework of the seven stages.

(a) Sporogenous mass stage: This stage is marked by the complete cessation of cell division in both: the sporogenous and tapetal tissues and by a considerable enlargement of their nuclei. Each tapetal cell is uninucleate and bounded by a primary wall. The chromatin of microsporocyte nuclei appears as a dense spherical body (Fig. 1). Differentiation of anther wall layers sets in showing larger tapetal cells and tangentially streched middle layer cells (Fig. 2).

(b) Meiosis I and II stage: this stage starts with meiotic leptotene and ends with initiation of tetrad formation. Meiosis is normal and from squash preparations the chromosome number determined is $\mathrm{n}=21$ at metaphase I and anaphase I. Meiotic prophase in PMCs is accompanied with highly synchronized karyokinesis in the tapetum and its cells become binucleate. Cells in both the tissues enlarge and occupy the space provided by the shrinkage of the middle layer (Fig. 3). The microspore mother cells, undergoing meiosis also form a hollow tube within the larger tube of tapetal tissue (Fig. 4).

(c) Tetrad stage: The enlargement of anthers leads to the separation of individual dyads and tetrads. The four meiotic products remain enclosed within a callose mother cell wall. The cells in middle layer and endothecium show further shrinkage and a loss of structural detail (Fig. 5).

(d) Free microspore stage: The release of young mictospores from the callose wall marks the beginning of free microspore stage. This stage is transitory as each microspore soon undergoes rapid growth and it gives rise to uninucleate pollen. The cells of middle layer are disorganized completely.

(e) Vacuolate microspore stage: The young microspores rapidly increase in size and develop many vacuoles, which ultimately merge into a large central vacuole occupying almost the entire cell with only a thin cytoplasmic layer along the wall. This is accompanied by tapetal disintegration as is marked by their shrinkage and loss of protoplasmic contents.

(f) Vacuolate pollen stage: By the time the pollen grains reach vacuolate stage, the tapetal cells degenerate almost completely, leaving only a limited number of their narrow 
Table 1. Enumerating the abnormalities observed during anther development in an exotic and six indigenous cytoplasmic male-sterile lines of wheat

\begin{tabular}{|c|c|c|c|c|c|c|c|c|}
\hline \multirow{2}{*}{$\begin{array}{c}\text { Stage } \\
\text { of } \\
\text { development }\end{array}$} & \multirow{2}{*}{ Abnormality } & \multicolumn{7}{|c|}{ Cytoplasmic male-sterile line } \\
\hline & & Nadadores & $\mathrm{HD}_{1593}$ & $\mathrm{HD}_{2009}$ & $\mathrm{~K}_{7435}$ & $\mathrm{UP}_{368}$ & $\mathrm{WH}_{157}$ & $W_{711}$ \\
\hline \multirow[t]{4}{*}{ Pre-meiotic } & $\begin{array}{l}\text { 1. Degeneration of either sporoge- } \\
\text { nous tissue, dyad or tetrad fol- } \\
\text { lowed by degeneration of tapetum }\end{array}$ & & + & + & + & & + & + \\
\hline & $\begin{array}{l}\text { 2. Degeneration of tapetum followed } \\
\text { by degeneration of sporogenous } \\
\text { tissue, dyad or tetrad }\end{array}$ & & + & + & + & & + & + \\
\hline & $\begin{array}{l}\text { 3. Tapetal pseudoperiplasmodium } \\
\text { development }\end{array}$ & & & & + & & & \\
\hline & $\begin{array}{l}\text { 4. Tapetal hypertrophy at sporo- } \\
\text { genous mass stage }\end{array}$ & + & & & & & + & \\
\hline \multirow[t]{5}{*}{ Post-meiotic } & 5. Tapetum persisting up to anthesis & + & + & + & + & + & & \\
\hline & 6. Undifferentiated tapetum & & & & + & + & & \\
\hline & $\begin{array}{l}\text { 7. Tapetal hypertrophy at microspore } \\
\text { stage }\end{array}$ & + & & & & & & \\
\hline & $\begin{array}{l}\text { 8. Tapetum degenerating at late } \\
\text { vacuolate pollen stage and fibrous } \\
\text { bands appearing on radial walls } \\
\text { of endothecial cells }\end{array}$ & & & + & + & & & \\
\hline & $\begin{array}{l}\text { 9. Pseudoperiplasmodium developing } \\
\text { at pollen grain stage }\end{array}$ & & & & & & & + \\
\hline
\end{tabular}

protoplasmic fragments. Uni-, bi- or trinucleate pollen grains develop a thick exine. In this stage the characteristic fibrous thickening on the radial walls of endothecial cells starts to appear.

(g) Mature pollen stage: During the mature pollen stage the vacuole disappears and the pollen acquires dense, granular and dark stained cytoplasm filled with starch and other reserves. The fibrous bands in endothecial cells are fully developed at this stage while the tapetal cells are by now completely used up (Fig. 6). The mature pollen grains are possessing three nuclei, oval shaped with thick exine having a single circular germ pore.

In the anther, the procambial strands of the connective differentiate in to well developed xylem elements enclosed by phloem tissue during meiosis stages I and II.

\section{B. Anther ontogeny in male-sterile lines:}

Ontogeny of anthers of exotic as well as indigenous male-sterile lines exhibits a number of abnormalities during pre-meiotic and post-meiotic stages, as summarized in Table 1.

1. Nadadores: Early ontogeny of anthers up to pre-meiotic stage, resembles that of fertile line. However, a number of abnormalities in subsequent stages are exhibited by wall layers, sporogenous tissue, microspores and anther connective.

The cells of epidernal layers elongate normally in tangential direction with their cuticle poorly developed. The endothecial cells fail to elongate radially with no fibrous bands on their radial walls. The middle layer in most of the anthers collapses at early microspore stage, only in a limited number of anthers do these cells persist up to anthesis.

The reduction in the number of anther lobes is a common feature of 'Nadadores' line. On accout of this the anthers are found to be either bi- or tri-sporangiate. It 


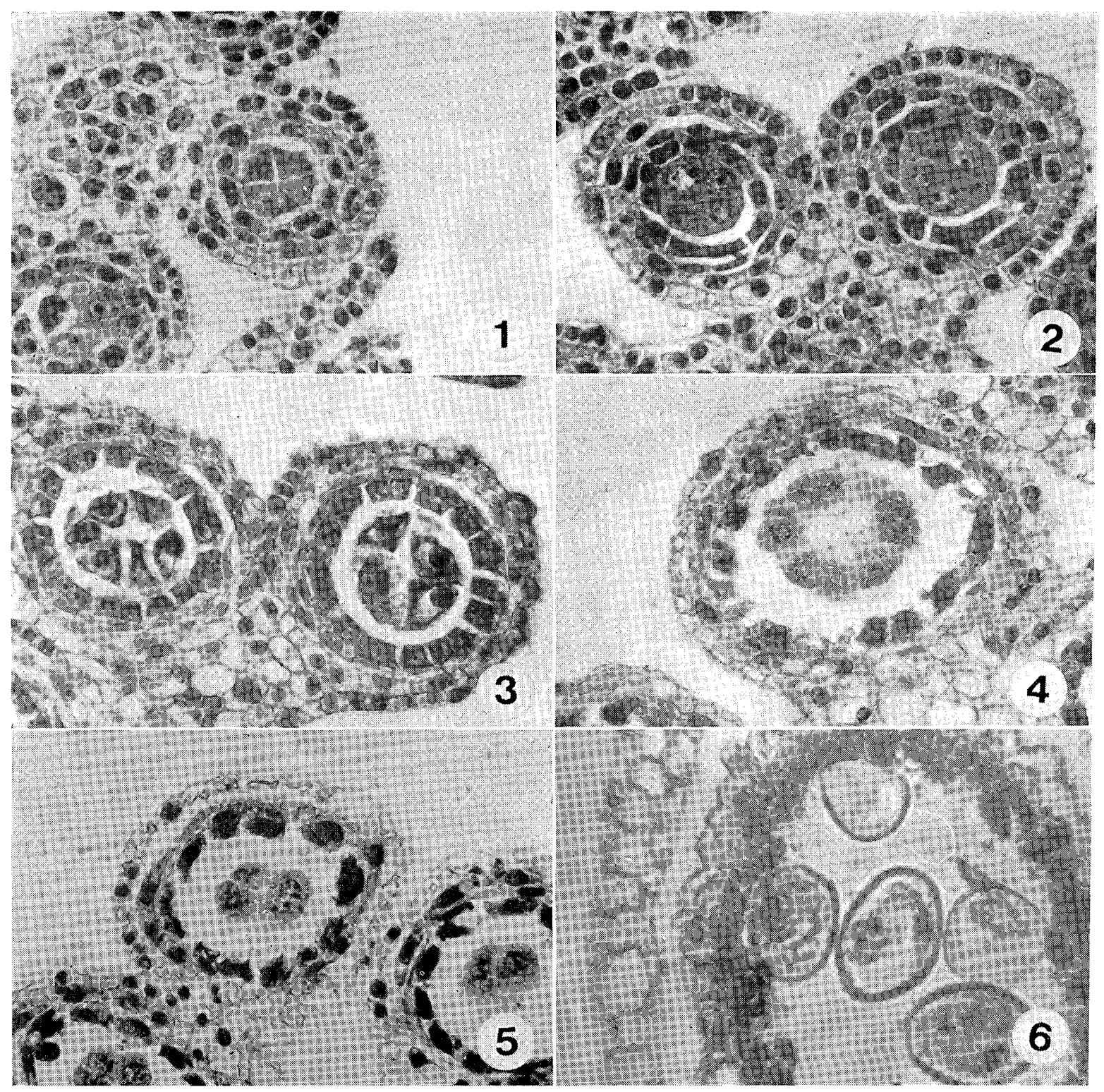

Figs. 1-6. Transverse sections of anthers of male-fertile lines. $210 \mathrm{X}$

Fig. 1. Early sporogenous tissue stage.

Fig. 2. Sporogenous tissue stage with all the wall layers.

Fig. 3. Late sporogenous tissue stage.

Fig. 4. Meiosis I and II stage.

Fig. 5. Tetrad stage.

Fig. 6. Mature pollen grain stage, 


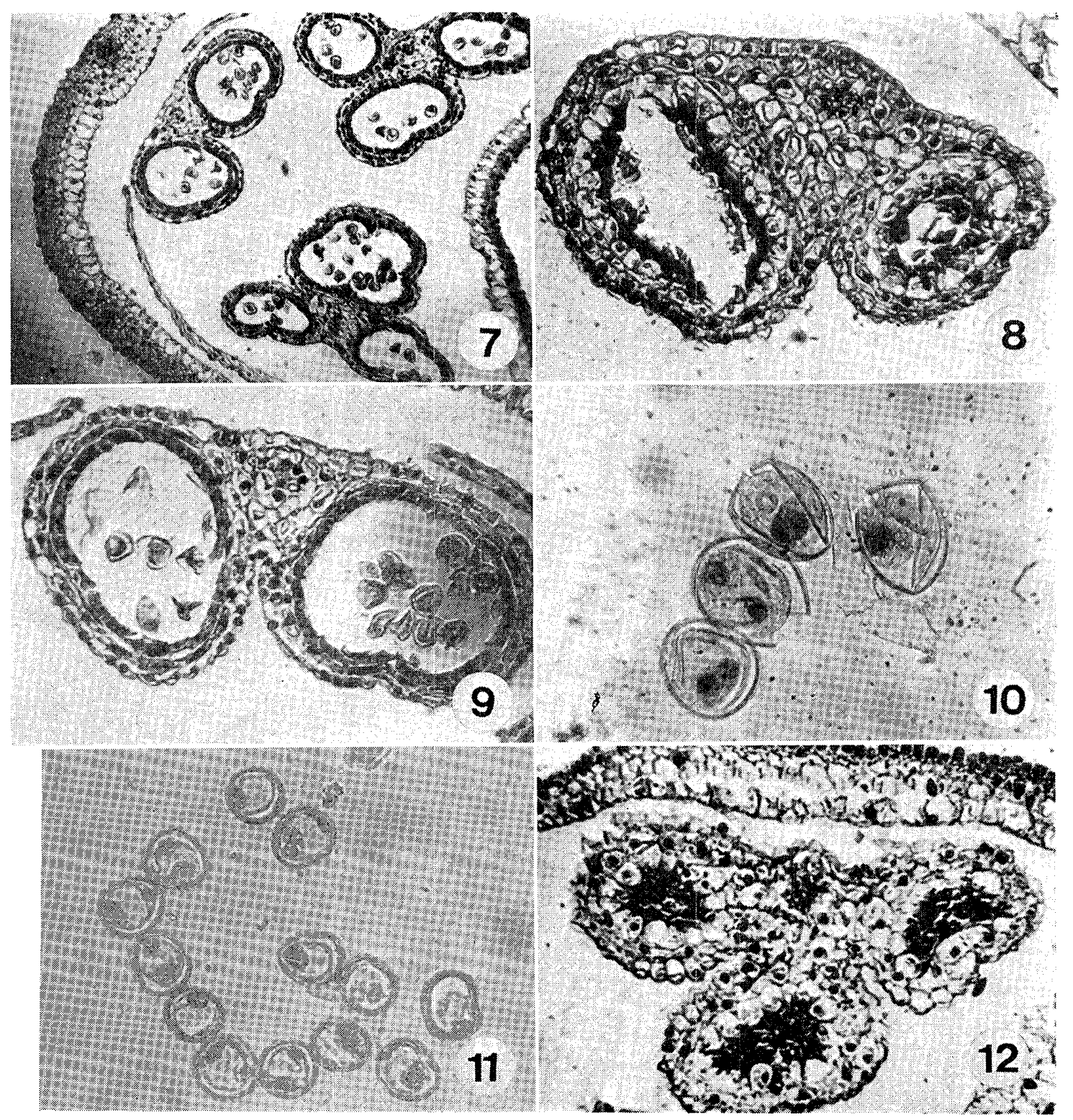

Figs. 7-12. CMS 'Nadadores' line.

Fig. 7. Transverse section of a floret showing reduction in the number of anther lobes. $90 \mathrm{X}$

Fig. 8. Transverse section of a bi-sporangiate anther showing tapetal hypertrophy at sporogenous tissue stage. $210 \mathrm{X}$

Fig. 9. Transverse section of a bi-sporangiate anther with tapetum persisting at vacuolate pollen stage. $210 \mathrm{X}$

Fig. 10. Bi-celled pollen grains with well developed exine having a germ pore. $240 \mathrm{X}$

Fig. 11. Bi-celled pollen grains with well developed exine having a germ pore. $210 \mathrm{X}$

Fig. 12. Transverse section of a tri-sporangiate anther showing tapetal hypertrophy during postmeiotic stage. $210 \mathrm{X}$ 


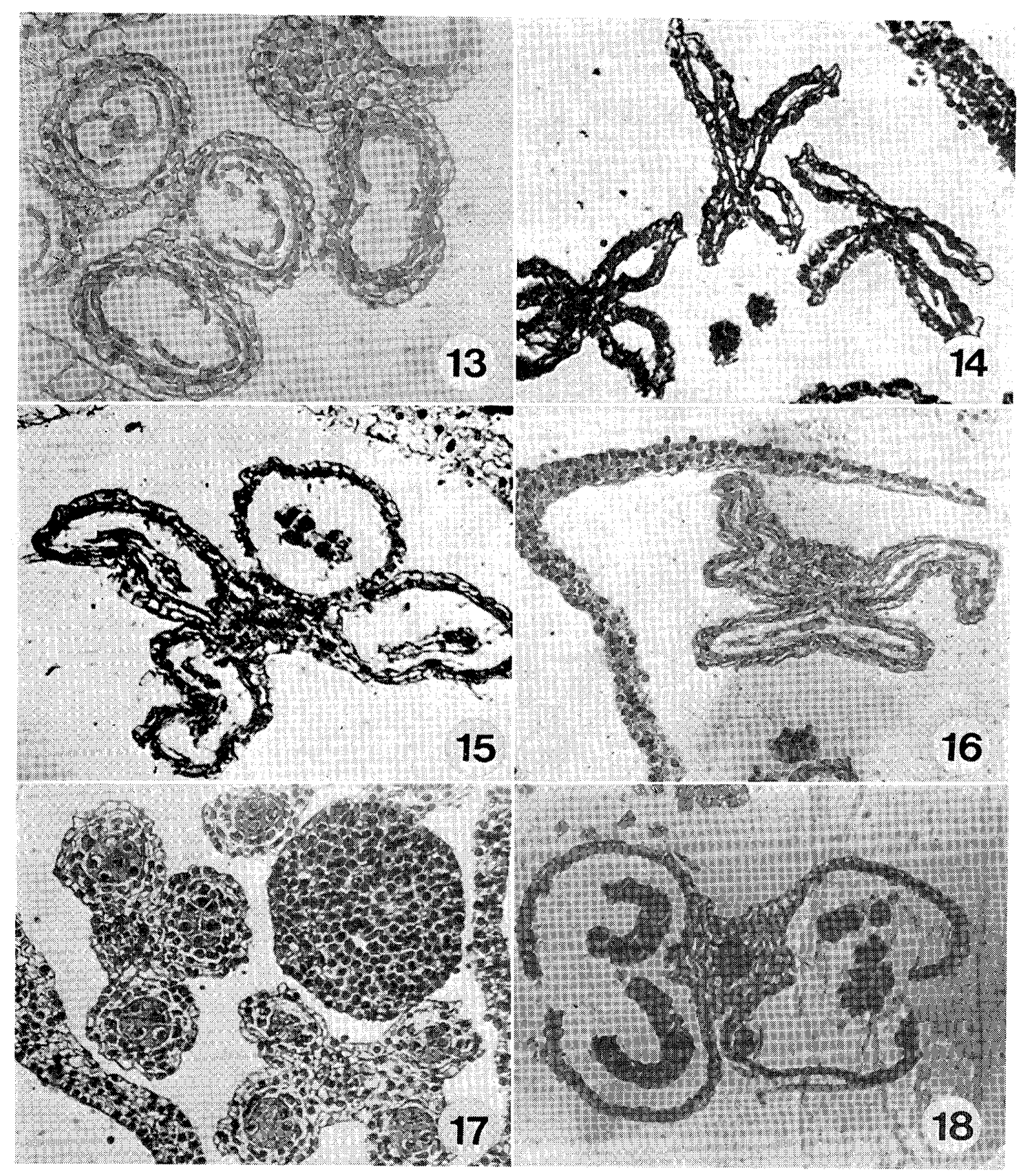

Figs. 13-18. Transverse sections of anthers of indigenous CMS lines.

Fig. 13. $\mathrm{HD}_{1593}$ showing degenration of tapetum at early meiotic stage. $120 \mathrm{X}$

Fig. 14. $\mathrm{HD}_{2009}$ showing empty anther. $120 \mathrm{X}$

Fig. 15. $\mathrm{K}_{7435}$ showing pseudoperiplasmodium" at PMCs stage. $210 \mathrm{X}$

Fig. 16. $\mathrm{K}_{7435}$ showing complete degeneration. $210 \mathrm{X}$

Fig. 17. $\mathrm{UP}_{368}$ showing undifferentiated wall layers at sporogenous tissue stage. $120 \mathrm{X}$

Fig. 18. $\mathrm{WL}_{711}$ showing pseudoperiplasmodium at pollen grain stage. $120 \mathrm{X}$ 
is interesting to note that the reduction in the sporangial number is usually shown by the central stamen which is affected first, followed by the lateral ones (Fig. 7).

The deviation of tapetum from normal course makes it necessary to emphasis these for the sake of clearity.

a. Tapetal hypertrophy in pre-meiotic stages: The tapetal cells are found to elongate radially and become hypertrophied at pre-meiotic stage of some flowers in a hundred of spikelets. Their sporogenous cells are thus crushed by this abnormal enlargement of tapetal cells even prior to the onset of meiosis (Fig. 8).

b. Non-degeneration and persistant tapetum: The tapetal cells remain intact up to anthesis in most of the flowers of the spike. The intact tapetal cells stretch tangentially and at mature pollen stage, possess deeply stained protoplast with degenerated nuclei. Such anthers contain non-viable pollen grains characterized by their shrivelled nature and lack of granular cytoplasm (Fig. 9). However, exine development is not much inhibited and a circular germpore is invariably present (Fig. 10). The squashes of mature anthers showed that mostly only uninucleate pollen grains aborted but a limited number of binucleate and trinucleate pollen grains with scanty degenerated protoplast are also discernible (Fig. 11).

c. Tapetal hypertrophy in post-meiotic stage: In another limited number of flowers of some spikelets, intact tapetal cells enlarge in radial direction and become hypertrophied at early microspore stage. The tapetal cells occlude the anther sac and crush the microspores. Hypertrophied tapetal cells possess scanty cytoplasm with large vacuoles and degenerated nuclei (Fig. 12).

The anthers exhibiting the above mentioned types of abnormalities show inhibition of vascular differentiation. The vascular tissue: may remain pro-cambial, while in the case of tapetal cells remaining intact, a large number of thin walled narrow xylem elements appear with degenerating phloem on its periphery (Fig. 9).

2. $H D_{1593}$ : In most of anthers of this male-sterile line, pollen abortion is seen associated with persistant tapetum similar to that of CMS 'Nadadores'. However, in a limited number of anthers either sporogenous tissue," pollen mother cells, dyads or tetrads degenerate causing complete sterility. This is followed by the degeneration of tapetum. In still other cases exhibited by a limited number of flowers, the tapetal cells degenerate at early meiotic stages (Fig. 13). This is followed by the degeneration of PMCs. Vascular tissues in either case remain undifferentiated.

3. $H D_{2009}$ : This male-sterile line, besides exhibiting intact tapetum associated with pollen abortion, also exhibits either complete degeneration of sporogenous tissue followed by tapetal degeneration or vice-versa. Such anthers: are empty and are enclosed by epidermal layer alone. However, at places, endothecial cells are also seen (Fig. 14).

4. $K_{7435}$ : The male sterile line $\mathrm{K}_{7435}$, peculiarly enough, showing tapetal pseudoperiplasmodium at PMCs stage is of frequent occurrence (Fig. 15). The plasmodium degenerates along with the PMCs (Fig. 16). In other respects, it resembles in behaviour of its tapetum with $\mathrm{CMS}_{\mathrm{HD}_{2009}}$ line. In, somecases, however, confined only to a limited 
number of flowers, tapetum degenerates at the late vacuolate pollen grain stage. This is followed by the appearance of fibrous bands on the radial walls of endothecial cells.

5. UP $P_{368}$ : The development of male-sterile anthers of CMS $\mathrm{UP}_{368}$ is similar to CMS $\mathrm{HD}_{2009}$. An interesting finding of tapetal cells in this line is that tapetum fails to give any impression of being a metabolic jacket at any stage as its cells possess poorly stained scanty protoplast (Fig. 17). In a limited number of anthers tapetal degeneration occurs at late vacuolate pollen stage followed by the formation of fibrous bands in the endothecial cells as shown by $\mathrm{CMS} \mathrm{K}_{7435}$ line.

6. $W H_{157}$ : This CMS line also exhibits degeneration of either sporogenous tissue, PMCs, dyads or tetrads as recorded in $\mathrm{CMS} \mathrm{HD}_{593}$ line. Poorly differentiated tapetum and tapetal hypertrophy in pre-meiotic stages are also of frequent occurrence apart from persistance of tapetum up to anthesis.

7. $W L_{711}$ : Persistant tapetum similar to other CMS lines is a common feature. Besides, a limited number of anthers also exhibit tapetal degeneration at meiotic stages followed by the degeneration of PMCs. Tapetal pseudoperiplasmodium developing at pollen grains stage is of frequent occurrence (Fig. 18). The plasmodium degenerates along with the pollen grains.

\section{Discussion}

It is clear from the foregoing description of anther ontogeny in male-fertile and the CMS variety 'Nadadores' that abortion of pollen in this line is associated with nondegeneration and persistant tapetum. The tapetal cells in the anthers of CMS Nadadores persist throughout the course of development, rendering the microspores non-viable. Similar observations have also been recorded earlier in CMS wheat by CHAUHAN and SingH (1966) and Joppa et al. (1966). In the opinion of the present authors, the persistance of tapetum beyond certain stage seems to be deleterious for growth of microspores. The nondegeneration of tapetal cells may be responsible for not allowing the required nutrition to be transferred to the developing microspores which consequently abort. This interpretation is corroborated by the general appearenace of tapetal cells and the vascular inhibition in such anthers. Further, poor staining capacity of tapetal cells in a limited number of anthers reflects their low metabolic state. Therefore, such malfunctioing tapetum, in the opinion of the present authors is neither capable of metabolizing anything nor capable of transferring nutrition to the developing microspores (see Echlin 1971). This hypothesis is further supported by the hypertrophying of tapetal cells in a limited number of CMS Nadadores anthers as suggested earlier by ChAuHAN and Singh (1968) that the starving tapetal cells become haustorial in search of nutrition.

The formation of pseudoperiplasmodium in the anthers of CMS $\mathrm{K}_{7435}$ and $\mathrm{WL}_{711}$ lines also seems to hinder the development of normal pollen grains, since their fertile counterparts exhibit only glandular tapetum. This is strongly supported by the observations of Singh (1936) in Ranunculus scleratus. According to him, this plant shows glandular tapetum and rarely did periplasmodium develop, but whenever it was associated with 
pollen abortion.

The anther ontogeny in the indigenous CMS lines developed through crosses with exotic variety 'Nadadores' also indicates similar mechanism of pollen abortion. However, a few other tapetal abnormalities in indigenous varieties have also been recorded as follows.

(i) Degeneration of tapetum followed by degeneration of sporogenous tissues or vice-versa has been recorded in $\mathrm{CMS} \mathrm{HD}_{1593}, \mathrm{CMS} \mathrm{K}_{7435}, \mathrm{CMS} \mathrm{HD}_{200}, \mathrm{CMS} \mathrm{WH}_{157}$ and CMS WL W $_{71}$ lines. Recent ultrastructural studies have indicated the presence of plasmodesmatal bridges between sporogenous and tapetal cells dueing pre-meiotic stages (Mascarenhas 1975). The premature breadkown of either tapetum or sporogenous cells breaks the communication between the two tissues and finally causes complete sterility.

(ii) In the anthers of CMS $\mathrm{K}_{7435}$ and $\mathrm{CMS} \mathrm{WL}_{711}$ lines, pseudoperiplasmodium develops at different stages of development, causing pollen abortion.

The above mentioned tapetal abnormalities, in the opinion of the present authors are caused by inhibition of vascular differentiation in the anther connectives. The occurrence of aditional abnormalities in indigenous CMS lines may be due to the action of some other factors interacting with exotic cytoplasm of 'Nadadores'.

\section{Acknowledgements}

Sincere thanks are due to Dr. Bahadur Singh, Retired Sientist, C.S.I.R. for going through the manuscript; to Dr. S. N. Chaturvedr, Reader and Head for encouragement; to Dr. Roshan Singh, Principal for facilities and to Dr. D. L. Kerm for seeds.

\section{Literature Cited}

Chaunan, S. V.S. and S.P. Singh 1966. Pollen abortion in male-sterile hexaploid wheat (Norin) having Aegilops ovata L. cytoplasm. Crop Sci. 9:532 535.

$\longrightarrow$ and 1968 . Studies on pollen abortion in Cucumis melo L. Agra Univ. J. Res. (Sci.) $17: 11 \sim 22$.

Duvick, D. N. 1968. Use of male sterility in the breeding of outcrossing crops. Proc. XII Internat. Congress Genet. II : 228 229.

Ecrirrn, P. 19715. The role of tapetum during microsporogenesis of angiosperms. In : Pollen: Development and Physiology. Ed. J. Heslop-Harrison. Butterworths, London, P. 41 61.

Fukasmwa, H. 1953. Studies on restoration and substitution of nucleus (genome) of Aegilotriticum. I. Appearance of male-sterile durum in substitution crosses. Cytologia $18: 167 \sim 175$.

1959. Nucleus substitution and restoration by means of successive backcross in wheat and its related genus Aegilops. Japan. J. Bot. $17: 55 \sim 91$.

Heyne, E. G. and R. W. Livers 1968. Use of male sterility in the breeding of self-pollinated crops. Proc. XII Internat. Congress genet. II : 230 231.

Joppa, L.R., P. II. McNeal and J.R. Welsh 1966. Pollen and anther development in cytoplasmic male sterile wheat (Triticum aestivum L.). Crop Sci. $6: 296 \sim 297$.

KinARA, H. 1951 Substitution of nucleus and its effects on genome manifestations. Cytologia $16: 177 \sim 193$.

Mascarenhas, J. P. 1975. The biochemistry of angiosperm pollen development. Bot. Rev. 41:259 314.

Singh, B. 1936. Life history of Ranunculus scleratus L. Proc. Ind. Acad. Sci. $4: 75 \sim 91$.

WILson, J.A. and W. M. Ross 1962. Cross breeding in wheat, Triticum aestivum L. II. Hybrid seed set on a cytoplasmic male-sterile winter wheat composite subjected to cross-pollination. Crop Sci. $2: 415 \sim 417$. 
Triticum timopheevi の細胞質で置換した 7 種のパンコムギ 雄性不稔系統飞和讨る葯の発育異常

A. K. JAIN*，R.K.S.RATHORE*，S.V.S. ChAUHAN*，木下俊郎** (*インド R.B.S. 大学, **北海道大学農学部)

パンコムギの近縁種 Triticum timopheevi の細胞質を置換して作成した雄性不稔系統 'Nadadores' (米国コ ロラド州カーギル研究農場産) を老細胞質提供親として, インドの在来品種 6 種とそれぞれ交配し, さらに各在来 品種を連続戻し交配して6 種の雄性不稔系統を育成した。これらと原敀種 ‘Nadadores’ とを用いて, 花粉退化 に至るまでの葯の発育異常について比較観察を行った。

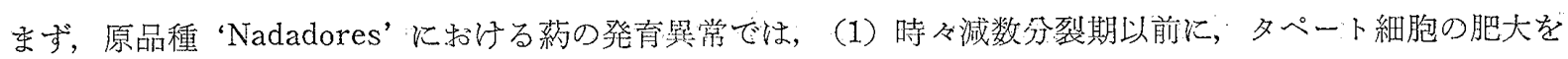
生じ，花粉母細胞の退化を起こすことがある。(2) 大部分の小花で起こる現象として，開花に至るまでタペー ト組織が崩壞せずと残存する。そのため，小胞子の外皮の発達が抑制され，不完全花粉を生ずる。（3）時には， 小胞子形成初期にタペート細胞が放射状飞肥大し，小胞子を斥迫して退化せしめる。一力，インド在来品種の 核より成る 6 種の雄性不稔系統でも上記の上うなタペート輿常を生でたが，その外飞，下記の如き異常を生じ た。（1）減数分裂期初期にタペート組織の崩壊に伴い，花粉母細胞や花粉四分子が崩壤する。（2）減数分裂期 以前をたは以後の時期に，タペート組織が周辺㑇变形体 (Pseudo-periplasmoditm) を形成し，小胞子の買常を 起こすั。

これらのタペート珙常は，葯隔に抢汗る維管束系の発達抑制之関連するものと考光られる。また，インド在

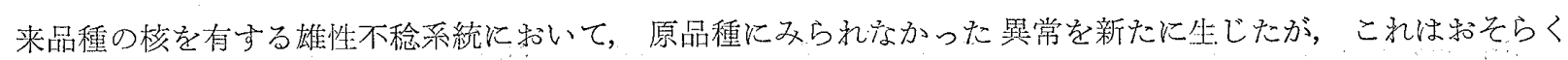
timopheevi 細胞質とインド在来品種の核に抢汀る遺伝要因間の相互作用に起因するものであるう。 